\title{
CORRESPONDENCE
}

\section{Exposure to Asbestos}

SiR,-Your article "Exposure to Asbestos" (Nature, 234, 383; 1971) quoting work in a USA shipyard gives the impression that the present standards for maximum permitted levels of asbestos dust emission are too high:

Until 1968 the maximum permitted level for asbestos dust concentration in work areas in the USA was expressed in accordance with the standards of the American Conference of Government and Industrial Hygienists in millions of particles per cubic foot. The standard during the time at which the ship repair workers that you have reported were exposed was therefore the pre-1968 standard of 5 million particles per cubic foot.

Since asbestosis was not diagnosed in persons with less than 10 years of cumulative exposure, the only relevant dust counts are those for the pre-1961 period. The average level of dust concentration aboard ship where $98 \%$ of the man hours were spent, given in the New England Journal of Medicine, by the test method appropriate to the standard, was 7.2 m.p.p.c.f., in 1965 . For the only previous year quoted, 1945, the measurement, while taken by a different method, indicates levels nearly twice as high.

In 1968 the American standard was reduced from 5 m.p.p.c.f. to 2 m.p.p.c.f. or to 12 fibres/millilitre, since they regarded these as roughly equivalent.

The current threshold limit value in the USA is a time weighted average of 5 fibres/millilitre over an $8 \mathrm{~h}$ period with a peak not exceeding 10 fibres/ millilitre in a 15 min period. In the UK the Factory Inspectorate in interpreting the Asbestos Regulations 1969 has adopted a TLV of 2 fibres/millilitre and for concentrations between 2 and 12 fibres/millilitre over a $4 \mathrm{~h}$ period takes into consideration the level of concentration and duration of exposure.

Thus the levels at which the full provisions of the regulations are applied are in both countries well below the levels of shipboard exposure for pipe coverers on which you have reported. Yours faithfully, W. P. Howard

The Asbestos Information Committee, 10 Wardour Street,

London $W 1 \mathrm{~V} 3 H G$

\section{Heads in Bags}

SIR,-After Nature's excellent commentary on the Compton Report it was sad to find a scientist-Harald Trefall (Nature, 235, 347; 1972)-dealing so unscientifically with a more human problem. I would like to remind $\mathrm{Mr}$ Trefall of the point of the enquiry. If our civilized standards of justice are to mean anything, they must be defended against corruption by the sort of violence that they are supposed to be fighting. I am proud that my countrymen will go to considerable, though unhappily inadequate, lengths to maintain the standards of British justice. I am saddened that our forces of "law and order" act as though they are above the law; it is even sadder that $\mathrm{Mr}$ Trefall does not see the paramount importance of this.

Mr Trefall should also realize that if political arguments are to be settled by exchanging atrocity stories, much time can be saved by picking sides according to nationality-Irish or English, Israeli or Arab, and so on. If Mr Trefall were to study the recent history of Ireland, he would discover that the forces of "law and order" have seldom acted according to the standards of civilized justice, which gives some point to the resistance of many Irishmen to the forcible imposition of that same law and order. The concept of the justice of overthrowing tyranny by force is old and honourable-see the American Constitution. The blind worship of authority which Mr Trefall apparently advocates is even older, but much less honourable.

$$
\text { Yours faithfully, }
$$

$$
\text { R. W. FAKES }
$$

Biochemistry Department,

University College,

Gower Street,

London $\mathrm{WC1}$

\section{Semmelweiss in Translation}

SIR,-In a review by $\mathrm{E}$. Gaskell of $A$ History of Medicine (edited by Lester S. King; Penguin: Harmondsworth, 1971 ; 60p) which appeared in Nature of February 4, 1972, page 290, is a statement which implies that the works of Semmelweiss have never been trans. lated. This is not true, for $I$ have read a translation, by F. P. Murphy, of Die Aetiologie, der Begriff und die Prophy. laxis des Kindbettfiebers (Vienna: Hartleben, 1861) which appeared in Medical Classics, 5, 350-773 (Baltimore: Williams and Wilkins, 1941).

Yours faithfully,

$$
\text { C. E. D. TAYLOR }
$$

Director and Consultant

Microbiologist,

Public Health Laboratory and Department of Microbiology,

Central Middlesex Hospital,

Park Royal,

London NW10 7NS

\section{Obituary}

\section{Professor Emmanuel Fauré-Fremiet}

Professor EmManuel Fauré-Fremiet, cytologist, developmental biologist, and protozoologist, died on November 6, 1971 , in Paris.

Born on December 29, 1883, as the older son of the composer and organist Gabriel Fauré, Emmanuel spent much of his youth with his maternal grandfather, sculptor Emmanuel Fremiet, whose name both he and his brother adopted in the compound FauréFremiet.

For 60 years Fauré-Fremiet was associated with the Laboratoire d'Embryogénie Comparée, which became in 1955 the Laboratoire d'Embryologie Expérimentale, of the Collège de France. He took the chair there in 1928, succeeding his father-inlaw, and stayed there until his retirement in 1955. As "Professeur 


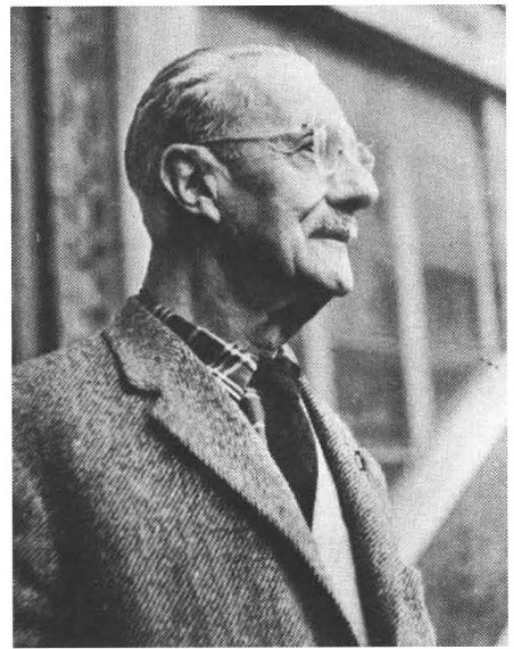

Courtesy of Mme Marie Fauré-Fremiet

honoraire", he continued in active research at the Collège de France and at Gif-sur-Yvette until his death. In 1929, 1933, and 1950, with the aid of Rockefeller Foundation and Commonwealth Fund grants, extensive trips were made to North and South America, with a short, final visit to the United States in 1970 .

Fauré-Fremiet's impact on science was as a theorist. His concepts and hypotheses have been as highly original as they are heuristic, whether in the field of protein chemistry or systematic protozoology.

A synthesizer and an innovator, he was also a pioneer in many of his observations-in his early work on protozoan contractile fibres (1904), his discovery of mitochondria in protozoa (1910), his study on the nature of collagen (1920s), and his early recognition of the evolutionary unity of diverse groups of the ciliate protozoa through common properties, both static and dynamic, of their infraciliature. Over 70 when he first took up electron microscopy, he instantly became a world leader in ultrastructural biology, once again comprehending the overall picture as well as producing superb electron micrographs-many of which are still unpublished - of formerly unknown or poorly understood cytoplasmic structures.

In his own research, and in that of his students and laboratory guests, Fauré-Fremiet contributed to four principal areas of biology: cytology, with emphasis on cellular constituents as revealed by light and, later in his career, electron microscopy; developmental biology, including experimental embryology, tissue culture, and diverse problems of growth and development; the physico-chemistry of fibrous proteins, a subject holding fascination for him throughout his active scientific life; and ciliate protozoology. The last area, to which Fauré-Fremiet devoted his greatest efforts during the last twentyfive years, may be subdivided into at least four parts: experimental morphogenesis, ecology, phylogeny and evolution and systematics. Most of his 500 publications deal with protozoological problems.

In all his works, although he gathered many original data from both field and laboratory observations, his most memorable contributions are in the realms of synthesis and of innovative hypotheses. Great embryologists, for example-men like Paul Weiss and the late Ross Granville Harrison--have mentioned how they were excited by Fauré-Fremiet's little-publicized book, La Cinétique du Développement, when it appeared in 1925.

An accurate measure of this modest but highly intellectual man's impact on the scientific world may be seen in the long list of honours conferred on him during his lifetime. He was active in many biological societies in France and abroad, but his principal honours were the elections to membership of the most prestigious academies and learned societies in the world. $\mathrm{He}$ was a Membre de l'Institut de France, Académie des Sciences, Foreign Fellow of the Royal Society, Foreign Associate of the National Academy of Sciences, Membre Etranger de l'Académie Royale Flamande des Sciences, des Lettres et des Beaux Arts, Membro Straniero della Accademia Nazionale dei Lincei, Honorary Foreign Member of the American Academy of Arts and Sciences, and Membro Correspondente dà Academia Brasileira dàs Ciencias. In the field of protozoology, as might be expected, Fauré-Fremiet was active in both national and international societies and congresses. $\mathrm{He}$ was elected an Honorary Member of the Society of Protozoologists, and Honorary President of the Second International Conference on Protozoology, held in London in 1965. He was also a founder member of the Groupement des Protistologues de Langue Francaise in 1961.

But Fauré-Fremiet was not simply a scientist. Inheriting the artistic abilities of his grandfather Fremiet, he produced several sculptures of value, some of which now stand in the parks and museums of Paris. In his younger days he also painted, and his graceful, lifelike sketches of species of protozoa, many of which are unpublished, are reminiscent of animal drawings made by his grandfather. He was also much in demand as a writer of obituaries for the many colleagues he outlived.

But, as well as being highly creative, Fauré-Fremiet could also be an extreme perfectionist-a quality not without its problems. The story is told that, in 1929, the late Maurice Caullery sent off to press the manuscript of a book on cytology prepared by Fauré-Fremiet while the latter was abroad for several months. When he returned, FauréFremiet was most upset and immediately withdrew the work from the publisher, with the comment that he must not only add a little new information to it, but also reshape the entire draft. The book never did appear.

Students or close associates numbered many over Fauré-Fremiet's long career, and numbers of them have gone on to establish their own reputations. A great friend to his fellow scientists, Fauré-Fremiet always had time for the questions of his students and colleagues.

Fauré - Fremiet married twice, although he died childless. In 1913 he married Jeanne Henneguy, daughter of Louis-Félix Henneguy the cytologist. Mme Fauré-Fremiet died in June 1967, and four years later, a mere five months before he died, Fauré-Fremiet married his secretary and research collaborator, Mlle Marie Hamard, who survives him.

Protozoologists, embryologists, and all who knew him will deeply mourn the loss of such a leader in science and a man of great humility and sensitivity.

\section{Announcements}

\section{University News}

Mr Maurice Graneek, PIRA, Leatherhead, has been appointed to the Bentley chair of manipulative machinery in the Department of Mechanical Engineering, Loughborough University of Technology.

Dr Jack Stevens, University of Chicago, has been appointed to the chair of orthopaedic and traumatic surgery, University of Newcastle upon Tyne.

Mr A. M. Walker has been appointed to a personal chair in the Department of Probability and Statistics, University of Sheffield, and Dr R. J. Connolly has been appointed to the second chair of psychology.

\section{Miscellaneous}

The Institution of the Rubber Industry has awarded the Colwyn Medal for 1971 to Professor J. D. Ferry, University of Wisconsin, and the Hancock medal for 1971 to Dr E. R. Gardner. Dr William C. Wake has accepted an invitation to deliver the Foundation Lecture in 1973.

Mrs B. P. Hall, British Museum (Natural History), has won the Stamford Raffles award of the Zoological Society of London, in recognition of her work on the taxonomy and zoogeography of birds. The Society's scientific medal has been awarded to Professor D. L. Lee, University of Leeds, for his work on parasitology, and to Dr P. L. Miller, 